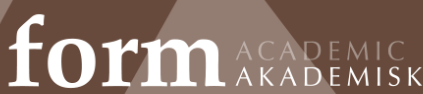

Vol I4, No 4 (202I)

\section{Eva Lutnæs \\ Professor (PhD) \\ Oslo Metropolitan University \\ evalu@oslomet.no}

Liv Merete Nielsen

Professor Emerita (PhD)

Oslo Metropolitan University

livmn@oslomet.no

Ingvild Digranes

Professor (PhD)

Western Norway University of Applied Sciences

indi@hvl.no

Editorial

\title{
Norwegian papers from the Academy for Design Innovation Management Conference - ADIM 2019
}

In June 19-21, 2019, Loughborough University London hosted the second Academy for Design Innovation Management Conference, Research Perspectives in the area of Transformations (Figure 1). Oslo Metropolitan University was one of the international partners along with 10 other universities. The conference attracted speakers and attendees from across the globe, including recognised industry professionals, international scholars and emerging researchers operating in the creative, commercial, and service industries. Erik Bohemia was one of the co-chairs and initiated bursaries to enable early career researchers from Global South countries to attend the conference. The opportunity to travel to conferences are not equally distributed and when registering for the conference all participants were asked to sponsor the fund. 


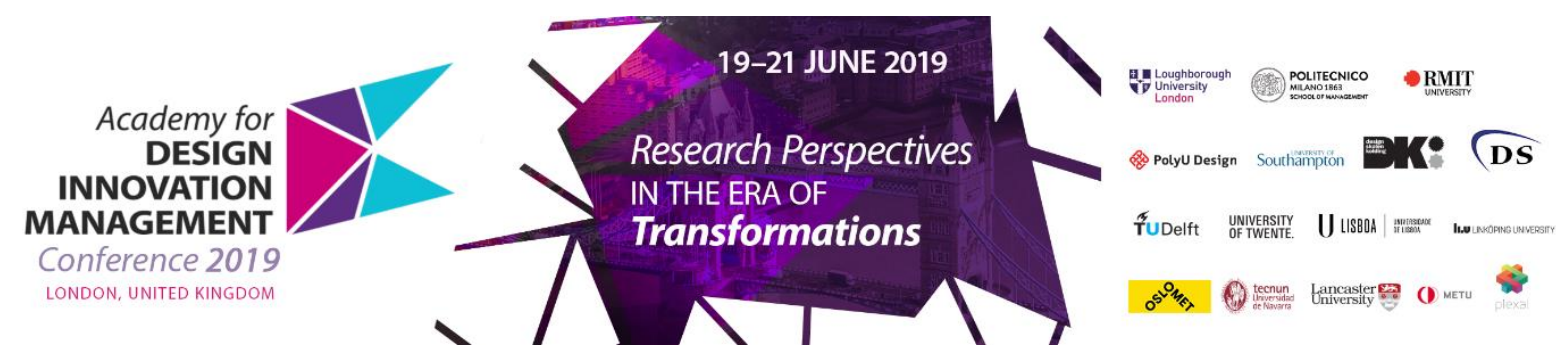

FIGUR 1. The logo for the conference.

The conference was an arena for establishing international networks e.g. by the collective research development workshop that connected early career researchers and doctoral students. A workshop chaired by Liv Merete Nielsen and co-chairs initiated the Design Literacy International Network (DLIN) (https://designliteracy.net).

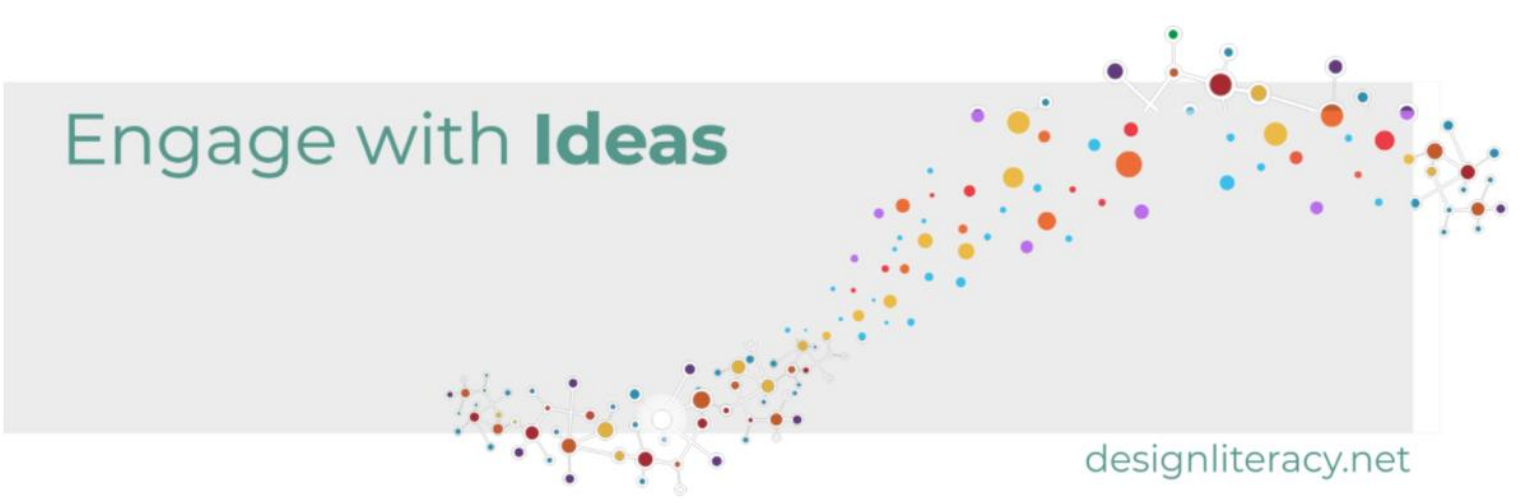

FIGUR 2. The Design Literacy International Network (DLIN) was established at the ADIM conference. DLIN arrange digital events where invited scholars from all over the world share their ideas on design literacy research.

The Norwegian contribution to the conference was solid. Norwegian research groups initiated two tracks with international co-chairs. Professor Ingvild Digranes at the Western Norway University of Applied Sciences and the research group Materiality, Technology, Sustainability (MaTecSus) accepted six papers for their track named Materiality in the Digital Age. The research group Design Literacy at Oslo Metropolitan University, led by Professor Liv Merete Nielsen, accepted 11 papers for their track named Design Literacy enabling Critical Innovation Practices. Professor Digranes and Professor Nielsen were responsible for the double-blind peer-review process for their tracks and the scientific quality of the conducted process. Two of the papers with Norwegian affiliation were awarded at the conference. The paper Framing the concept design literacy for a general public, authored by Eva Lutnæs was awarded Top III paper, and the paper Representations of Design Process, authored by Úrsula Bravo and Erik Bohemia was awarded Top III papers contributed by PhD candidates.

Due to a minor change in the title of the conference series, from Design Management Academy to Academy for Design Innovation Management, the ISSN (International Standard Serial Number) had to be revised. The new ISSN was applied for in November 2018 and approved by the ISSN UK Centre at the British Library. Unfortunately, The International ISSN Register confirmation was delayed and not received by December 31, 2019, the deadline for 2019 at NSD (Norsk senter for forskningsdata) [The Norwegian Centre for Research Data]. According to Register over vitenskapelige publiseringskanaler [The Norwegian Register for Scientific Journals, Series and Publishers] to be included at level 1 and count as a scientific publication channel in the Norwegian financial system, the following requirements must be fulfilled:

Journal/Series must 
- $\quad$ Be identified with a valid ISSN, confirmed by The International ISSN Register (demand from 2014)

- Have an academic editorial board (or an equivalent) primarily consisting of researchers from universities, institutes or organizations that do research

- Have established procedures for external peer review

- Have a national or international authorship, meaning that maximum 2/3 of the authors can belong to the same institution

(Direktoratet for høgare utdanning og kompetanse [The Norwegian Directorate for Higher Education and Skills], n.d.)

The conference series fulfilled all the special requirements for Norway, except the deadline for The International ISSN Register's confirmation of the new ISSN. Consequently, the Norwegian papers were not awarded publication credits through CRISTIN (Current Research Information System in Norway) due to this small change of the name of the conference series, although all these papers met all the criteria for scientific standard, including double blind peer review. To correct this injustice FormAkademisk research journal of design and design education publish the Norwegian papers in this special issue to ensure that they get the publishing points they are entitled to. By this special issue we want to make the Norwegian contributions available for students and scholars.

\section{Papers in this issue}

Peter Haakonsen and Laila Belinda Fauske, Oslo Metropolitan University, Norway, authored the first paper Learning to create images with computer code. They address the fact that programming is becoming a part of the school curricula in Norway both in lower and upper secondary education in subjects such as art, design and craft. The as questions regarding what programming can to the learning processes of these subjects. The concept of 'Tinkering' is introduced, to describe a creative phase in a learning/working process, emphasising both creation and learning. In the project that they present, visual images are created via computer programming to enhance the main author's learning. The paper discusses tinkering as a learning process that is relevant and motivating in relation to programming within art, design and craft education.

Ingvild Digranes, Jon Øivind Hoem and Arnhild Liene Stenersen, Western Norway University of Applied Sciences, Norway, has co-authored the paper Learning about materiality through tinkering with Micro:bits. This paper discusses two pilot projects in Art and design education at the teacher training at Western Norway University of Applied Sciences. As a point of departure, the pilots try to address the new curriculum of Art and design, where digital knowledge is described as stretching from using simple digital resources to master and shape your own digital products. In general design education the digital is no longer limited to two-dimensional visual modelling as previously practiced. This new approach in a subject where making and materiality is central, tinkering and designing allows for explorations in both $2 \mathrm{D}$ and $3 \mathrm{D}$. The pilot case studies demonstrate the importance of bringing coding and the material aspects of tinkering, making, and creating into play in combination.

Ingvard Bråten and Jon Øivind Hoem, Western Norway University of Applied Sciences, Norway, authored the paper Experiencing (from) the inside - Mediated perspectives in kindergartens. His paper presents a case study of preservice kindergarten teachers' use of new form of digital imagery. The paper introduces spherical cameras and digital microscopes and discusses their affordances when introduced in practical use in teacher education and in kindergartens. The use in kindergartens was introduced through a class of 34 teacher students in kindergarten education. The students were specializing in Arts and design at Western Norway University of Applied Sciences. The use of images from spherical cameras and digital microscopes were analysed based on data from student responses through two questionnaires, group presentations and discussions in class, and an analysis of various media material produced by students.

Liv Mildrid Gjernes, Western Norway University of Applied Sciences, Norway, authored the final paper of the track, Aarup 1960 and the poetics of materials. It has as its premise that all design has its own conditional modes of expression; however, these are realised through the maker's sense of the possibilities of materiality. The essay takes inspiration from a reclaimed piece of 1960s furniture de- 
signed in the modernist idiom, and is based upon autobiographical experiences, original works from own and contemporary aesthetic practices, and associated thoughts in the present. A completely new artistic expression is developed, questioning the strict, use-defined style ideals and letting shape reveal other values and statements than function. The essay succeeds in putting into words how some of the cognitive processes in which creativity, critical reflection and the senses' experience-based insights may bring up something new. It highlights that in creative work, the goal is not to reach a single result; every little discovery made by examining something specific could open up new worlds.

Eva Lutnæs, OsloMet - Oslo Metropolitan University, Norway, authored the first article Framing the concept design literacy for a general public. She explored the concept design literacy from a general public perspective. Asking the question 'What does it mean to be design literate in a context of critical innovation' she reviews three key texts storylines on how to cultivate design literacy and arrives at a definition of the concept design literacy for a general public. Lutnæs was awarded Top III Paper submissions for her contribution to the conference. Her paper was used as a point of departure for discussions in the Design Literacy workshop.

Tore Andre Ringvold and Liv Merete Nielsen, both Oslo Metropolitan University, Norway, had written the paper Complexity, interdisciplinarity and design literacy. For decades, global organisations and researchers have pointed to interdisciplinarity as a way forward for educational systems. Educational research offers great possibilities and gains for students involved in interdisciplinary teaching and learning processes, and the interdisciplinary nature of design thinking and practice can play a vital role in interdisciplinary general education. This paper explores how future scenario-building, as part of general design education, can serve as a framework for inter-disciplinarity in general education and contribute to a better understanding of complex problems, challenges and design literacy.

Randi Veiteberg Kvellestad, Ingeborg Stana and Gunhild Vatn, all from Oslo Metropolitan University, Norway, had written the paper Working Together - Cooperation or Collaboration? where they elaborate on the difference between cooperation and collaboration through an action-research project in design education for specialised teacher training in design, arts, and crafts. At the Oslo Metropolitan University including the material areas of drawing, ceramics, and textiles. The project developed the participants' patience, manual skills, creativity, and abilities, which are important personal qualities for design education and innovation and represent cornerstones in almost every design literacy and business environment.

Irene Brodshaug and Janne Beate Reitan, both Oslo Metropolitan University, Norway, had writen the paper Networking for strengthening design literacy. This paper focuses on design education for the general public and the ways in which students and teachers can become more design literate through the development of networks, such as professional groups for teachers. The emphasis of this study is on how each municipality gives time and space for the development of design competence through professional groups. A well-organized professional group will hopefully contribute to a deeper level of expertise in schools and an increased ability for the general public to recognize design education.

Anita Neuberg, Oslo Metropolitan University, Norway, presented her paper Social innovation for modified consumption by means of the school subject Art and craft. In her paper she asked: How can we, based on the subject of Art and craft in primary schools, facilitate the change in consumption through social innovation? Opportunities for actions were discussed under the subject of Art and craft, in Norwegian general education, ages 6-16.

Úrsula Bravo, Universidad del Desarrollo, Chile, and Erik Bohemia, Oslo Metropolitan University, Norway, wrote the paper Representations of Design Process where they argue that visual representations of design processes contribute toward social and material practices of design(ing). Metaphors was used to illustrate that they are active material devices of which circulation, production and consumption are informed and informing perceived complexities, ambiguities and paradoxes associated with design. These models can contribute to the development of Design Literacies. Bravo was awarded Top III Paper submissions for PhD candidates. 
Eva LUTNÆES, Liv Merete NIELSEN \& Ingvild DIGRANES - Editorial

This special issue also includes the introductions to Track 6a (Digranes, et al., 2021), 6b (Nielsen, et al., 2021a) and the Design Literacy workshop (Nielsen, et al., 2021b).

Hamar, Oslo and Bergen, December 2021

Eva Lutnæs, Liv Merete Nielsen and Ingvild Digranes

Special Issue Editorial Team 


\section{REFERENCES}

Digranes, I., Gao, B., Nimkulrat, N., Rissanen, T., \& Lien, A. (2021). Editorial track 6.a Materiality in the Digital Age. FormAkademisk - research journal of design and design education, 14(4). https://doi.org/https://doi.org/10.7577/formakademisk.4663

Direktoratet for høgare utdanning og kompetanse [The Norwegian Directorate for Higher Education and Skills]. (n.d.). Criteria for Inclusion of Scientific Publication Channels.

https://kanalregister.hkdir.no/publiseringskanaler/OmKriterier.action?request_locale=en

Nielsen, L. M., Lutnæs, E., Porko-Hudd, M., Bravo, U., Cortes, C., Almendra, R. A., \& Bohemia, E. (2021a). Editorial track 6.b Design Literacy enabling Critical Innovation Practices. FormAkademisk - research journal of design and design education, 14(4). https://doi.org/https://doi.org/10.7577/formakademisk.4649

Nielsen, L. M. Bohemia, E., Reitan, J. B., Brænne, K., Bravo, U., \& Catalina, C. (2021b). Editorial workshop. Establishing Design Literacy International Network. FormAkademisk - research journal of design and design education, 14(4). https://doi.org/https://doi.org/10.7577/formakademisk.4650 